\title{
Dominant Risk Factors of Sexually Transmitted Infections (STI) for HIV at Ships Crew
}

\author{
Rizana Fajrunni'mah", Diah Lestari \\ Health Polytechnic of Jakarta \\ III Jakarta, Indonesia \\ *Corresponding author's email: rie.ners [AT] gmail.com
}

\begin{abstract}
Results of risk behavior surveys show that truck drivers, sailors and fishermen and other port workers include frequent workers moving the place or mobile (mobile population) is due to the nature of the work, and is a group that is prone to contracting HIV due to sexual behavior. Access to Sex Workers at the port is considered easier compared to other groups, because it can be obtained directly or indirectly through intermediaries. This study aims to determine the most dominant risk factors for sexually transmitted infections against HIV incidence in crew in the Tanjung Priok Port area. The study used a quantitative design, design cross sectional with 60 respondent. Primary data was collected through an anti-HIV questionnaire and examination.

The results showed that the risk factors for STIs that were associated with HIV incidence were variables of sex with non-permanent partners, frequent partner changes, number of sex partners, and buying sex. There was no relationship between the frequency of sex, condom use, alcohol consumption and the incidence of HIV. The dominant factor is often changing partners with $O R$ 32,173. This research is expected to be useful as a source of information and able to improve the quality of education and assistance provided by health workers to the community, especially $A B K$ for the prevention of sexually transmitted infections.
\end{abstract}

Keywords - Risk factors for STIs, HIV, ships crew

\section{INTRODUCTION}

There are an estimated globally 35.5 million people living with HIV and AIDS. HIV sufferers in Indonesia until September 2016 were 219,036 and 82,968 AIDS sufferers. There were a number of new patients in 201627,963 people with HIV and 3,679 people with AIDS. The highest number of HIV infections is in DKI Jakarta as many as 43,738, followed by East Java 28,979, Papua 23,450, West Java 21,281, and Central Java 15,710. The highest percentage of HIV risk factors were risky sex in heterosexuals (42\%), 39\% MSM, 14\% others, and 5\% use of unsterile needles [1].

The results of the risk behavior survey show that truck drivers, sailors and fishermen and other port workers, can be said to include workers who move frequently or mobile (mobile population) due to the nature of their work, and are a group that is prone to contracting HIV because of their sexual behavior. In this group the consistency of condom use during sex with non-permanent partners is still low, on average less than $11 \%$. This situation is exacerbated by the rampant sex industry which is often found along highways and around large seaports and fishing ports along the North Coast of Java and North Sumatra [2]. Access to sex workers (SW) at the port is considered easier compared to other groups, because it can be obtained directly or indirectly through intermediaries. This offer comes by itself without being searched, because it has become a habit of the ships crew to use SW services, so that brokers without hesitation offer services to find it. Sex peddlers in selling themselves also range from selling food, herbal medicine to openly offering services, so that the group's access to SW is not difficult [3].

Richard S Howard in his article entitled Business and Labor Face AIDS Crisis in Indonesia stated that the 3M phenomenon, Men, Mobility and Money is a key factor contributing to a large epidemic in many countries. This is because men who are mobile often have extra time and money to use to buy commercial sex as entertainment. This mobility and migration is actually not a risk factor for contracting HIV, but can create conditions so that a person becomes vulnerable to contracting HIV. Employee mobility contributes to the rapid spread of HIV because workers are far from their families and communities which makes it easier for them to be tempted to fulfill their sexual needs by buying sex from women sex workers who are also often migrating to get customers [4].

Tanjung Priok Port is an entry point for trade traffic between islands and between countries and is also 
vulnerable to the transmission of sexually transmitted diseases. Ships crew or Anak Buah Kapal (ABK), which is a component in the port community, is a target that is at high risk for contracting STIs including syphilis and HIV / AIDS, because they often use the services of sex workers. This is due to the duties and functions that have high mobility so that they have little time to meet family and often experience prolonged stress.

\section{RESEARCH METHODS}

This study used a quantitative research design with an observational (analytic designcross sectional) with independent variables and dependent variables collected at the same time or period. The sample of this study was 60 respondents. The sampling technique used non-probability sampling technique, namely consecutive sampling. The instrument or instrument in this study was a questionnaire and rapid HIV antibody $1 / 2$ test for HIV testing. Data analysis used univariate analysis, namely the percentage of each variable, bivariate analysis with chi-square and fisher exact, multivariate analysis with logistic regression. Ethical clearance was submitted through the Poltekkes Jakarta Research Ethics Committee III and obtained a certificate of ethics approval with No. KEPK-PKKJ3/005/IV/2017.

\section{RESEARCH RESULT}

Table 1. Characteristics of Respondents

\begin{tabular}{lcc}
\hline \multicolumn{1}{c}{ Characteristics } & Frequency & $\%$ \\
\hline Age & 1 & $1.7 \%$ \\
$<20$ years & 6 & $10 \%$ \\
20-24 years & 49 & $81.7 \%$ \\
25-49 years & 4 & $6.7 \%$ \\
> 50 years & & \\
Education & 8 & $13.3 \%$ \\
Elementary-Middle School & 39 & $65 \%$ \\
High School & 13 & $21.7 \%$ \\
College & & \\
Status Married & 24 & $40 \%$ \\
Not married & 36 & $60 \%$ \\
Married & & \\
Income & 16 & $26.7 \%$ \\
1-3 million / month & 27 & $45 \%$ \\
3-6 million / month & 17 & $28.3 \%$ \\
$>6$ million / month & & \\
Time of work/ship & 10 & $16.7 \%$ \\
1-3 years & 14 & $23.3 \%$ \\
3-5 years & 36 & $60 \%$ \\
$>$ 5 years & & \\
Sailing time & 23 & $38.3 \%$ \\
$<1$ month & 1 & $1.7 \%$ \\
1-2 months & 36 & $60 \%$ \\
$>$ 2 months & & \\
\hline
\end{tabular}

Table 1 shows the characteristics of respondents. The majority of ABK aged 25-49 years amounted to $81.7 \%$, high school education amounted to $65 \%$, married $60 \%$, income per month 3-6 million by $45 \%$, length of work> 5 years by $60 \%$, and sailing time> 2 months by $60 \%$. 
Table 2. STI Risk Factors

\begin{tabular}{|c|c|c|c|c|}
\hline \multirow[b]{2}{*}{ Variable } & \multicolumn{2}{|c|}{ Anti-HIV Examination Results } & \multirow{2}{*}{$\begin{array}{c}\text { OR } \\
(95 \% \mathrm{CI})\end{array}$} & \multirow[b]{2}{*}{$\mathbf{p}$} \\
\hline & $\begin{array}{c}\text { Nonreactive } \\
\text { n }(\%)\end{array}$ & $\begin{array}{c}\text { Reactive } \\
\text { n }(\%)\end{array}$ & & \\
\hline \multicolumn{5}{|c|}{$\begin{array}{l}\text { Sexual intercourse with } \\
\text { permanent partners }\end{array}$} \\
\hline No & $45(75 \%)$ & $1(1.7 \%)$ & $12,273(1,162-$ & 0,036 \\
\hline Yes & $11(18.3 \%)$ & $3(5 \%)$ & $129,620)$ & \\
\hline \multicolumn{5}{|l|}{ Often change partners } \\
\hline No & $54(90 \%)$ & $2(3.3 \%)$ & $27,000(2,412-$ & 0,019 \\
\hline Yes & $2(3.3 \%)$ & $2(3.3 \%)$ & $302,193)$ & \\
\hline \multicolumn{5}{|l|}{ Number of sex partners } \\
\hline 1 person & $41(80.4 \%)$ & $1(2 \%)$ & $20,500(1,823-$ & 0,015 \\
\hline$>1$ person & $6(11.8 \%)$ & $3(5.9 \%)$ & $230,515)$ & \\
\hline \multicolumn{5}{|l|}{ sex orientation } \\
\hline Female & $47(92.2 \%)$ & $4(7.8 \%)$ & - & - \\
\hline \multicolumn{5}{|l|}{ Frequency of having sex } \\
\hline $1-3$ times & $40(78.4 \%)$ & $2(3.9 \%)$ & $5,714(0,687-$ & 0,139 \\
\hline$>3$ times & $7(13.7 \%)$ & $2(3.9 \%)$ & $47,515)$ & \\
\hline \multicolumn{5}{|l|}{ Buying sex (SW) } \\
\hline No & $52(86.7 \%)$ & $2(3.3 \%)$ & $13,000(1,429-$ & 0,046 \\
\hline Yes & $4(6.7 \%)$ & $2(3.3 \%)$ & $118,279)$ & \\
\hline \multicolumn{5}{|l|}{ Condom use } \\
\hline Yes & $12(23.5 \%)$ & $1(2 \%)$ & $1,029(0,097-$ & 1,000 \\
\hline No & $35(68.6 \%)$ & $3(5.9 \%)$ & $10,853)$ & \\
\hline \multicolumn{5}{|l|}{ Consumption of alcohol } \\
\hline No & $38(63.3 \%)$ & $2(3.3 \%)$ & $2,111(0,275-$ & 0,595 \\
\hline Yes & $18(30 \%)$ & $2(3.3 \%)$ & $16,213)$ & \\
\hline \multicolumn{5}{|l|}{ Drug use } \\
\hline No & $56(93.3 \%)$ & $4(6,7 \%)$ & - & - \\
\hline \multicolumn{5}{|l|}{ previous STI history } \\
\hline No & $56(93.3 \%)$ & $4(6.7 \%)$ & - & - \\
\hline
\end{tabular}

Table 2 shows the results of the analysis b ivariat by using thetest chi-square according to the requirements that must be fulfilled by alternative readings withtest fisher exact. The results of the analysis are explained as follows: there is a relationship between sexual relations with non-permanent partners with a $\mathrm{p}$ value of $0.036(\mathrm{OR}=12.27)$. Changing partners frequently is also related to the results of HIV testing with a $\mathrm{p}$ value of $0.019(\mathrm{OR}=27,000)$. Furthermore, the number of sex partners is related to the results of HIV testing with a p value of $0.015(\mathrm{OR}=20.5)$. Variables buying sex have a significant relationship with the results of HIV testing with a $\mathrm{p}$ value of $0.046(\mathrm{OR}=13)$. While the frequency of having sex, condom use, alcohol consumption there was no significant relationship with the results of HIV testing with each $\mathrm{p}$ value of $0.139 ; 1,000 ; 0.595$. The variables of sex orientation, drug use, and previous STI history, cannot be analyzed further because the results of the independent variables are the same among all respondents, so there is no variation.

Table 3. Multivariate Analysis of Logistic Regression Final Model

\begin{tabular}{lrrrr}
\hline \multicolumn{1}{c}{ Variable } & \multicolumn{1}{c}{ B } & \multicolumn{1}{c}{ Wald } & P value & OR \\
\hline Often changing partners & 3,471 & 5,672 & 0.017 & 32,173 \\
Buying sex (WPS) & 2,752 & 3,899 & 0.048 & 15,677 \\
Constant & $-10,242$ & 10,120 & 0.001 & \\
\hline
\end{tabular}

Table 3 describes the final results of the logistic regression multivariate modeling of risk factor models , where two main variables, often changing partners and buying sex, were significantly related to the results of HIV testing. Changing partners often has a significant relationship to the results of HIV testing with a $p$ value of 0.017 and OR 32.17 . This means that ABK who often change partners have the chance to get the results of HIV reactive examination compared to ABK who do not often change partners after being controlled by variables buying sex. Likewise, buying sex has a significant relationship with the results of HIV testing with $p$ value 0.048 and OR 15.67. This means that ABK who buy sex are 15 times more likely to get HIV reactive than those who do not buy sex after variable control often changes partners. Based on the highest OR results it was found that variables often change partners have the greatest influence on the results of HIV testing. 


\section{DISCUSSION}

The results of anti-HIV testing are carried out to indicate that someone has HIV infection. The results of the study on crew at the Tanjung Priok Port were found to be majority not reactive at $93.3 \%$. But it must also be noted that $6.7 \%$ obtained reactive results. Although the numbers are not large, the results show that this group is at risk and contributes to an increase in HIV-AIDS cases in Indonesia. According to the HIV-AIDS Case Report in Indonesia until December 2016 sourced from the HIV-AIDS \& STI Information System (SIHA) application, the cumulative number of HIV infections was 232,323, with the highest number of HIV infections in DKI Jakarta $(45,355)$, followed by East Java, Papua, West Java and Central Java. This is an increase from previous reports that until September 2016 there were 219,036 HIV patients and the highest number of HIV infections, namely in DKI Jakarta as many as 43,738. A total of 14 cases were found in seafarers [1].

This increase in HIV-AIDS cases also occurred in several other countries. As in Bangladesh, there has been an increase in cases especially among injecting drug users (IDUs). Another seemingly vulnerable population group is migrant workers who leave their families and travel abroad to work. Fishermen, dock workers and rickshaw pullers represent the main client groups, followed by local and foreign seafarers and truck drivers. Returning from work in a high-prevalence country is one way HIV is transmitted to countries with low prevalence. Likewise, a study in Nepal found that the proportion of men working abroad and having sex with sex workers had higher rates of HIV infection than those who did not leave Nepal [5]. Other research results in Indonesia show that fishermen in Benoa Harbor, Bali have the same vulnerability to HIV infection as other cellular populations in the region and other parts of the world, especially those involved in circular migration from a male-dominated population bring HIV to rural communities [6]. Likewise in the Netherlands there is an increase in migration and traveling which can increase the prevalence of sexually transmitted infections [7].

HIV frequency in Iranian sailors was $0.25 \%$ of cases or only one positive HIV test was found. The likelihood for these results is that there is very little HIV infection in Iranian sailors or research samples that represent low-risk seafarers compared to seafarers in other countries. The study results are similar to some countries such as Britain and West Africa. But it shows a significant difference with Ethiopia and Spain [8]. The results of the study were also similar to the results of HIV testing in the Port of Juwana, Central Java, with 1 reactive person from 89 respondents [9].

The risk factors for STIs in this study which obtained a relationship with the results of HIV testing were sex with a non-permanent partner, frequent partner changes, the number of sex partners who were more than 1 person, and buying sex from Woman Sexual Workers. Sex with a non-permanent partner is a sexual relationship other than with the wife. ABK is a migrant worker who moves from home to family and a group that is prone to contracting HIV due to her sexual behavior. There were 3 ABKs with reactive results who said they had had sex with non-permanent partners, two of them were married. One crew member who married turned out to answer that she had bought sex, 1 other crew member who bought sex with an unmarried status. Based on the report on Biological Integrated Surveillance and the behavior of in 5 port locations [10], it was found that as much as 58\% of ABK related to Women Sex Workers in the past year, and $16 \%$ were related to their non-permanent partners. Workers who are far from their families and communities make it easy to be tempted to fulfill their sexual needs by buying sex [4].Living in a separate environment from family and traditional values of life makes young migrant workers tend to be motivated to risk sexual behavior as "recreation" [11]. Besides buying sex, other sex partners are girlfriends and friends. The most reason for having sex outside of marriage by the crew is that they need variety, fun, and invited friends. ${ }^{3}$ It is also shown from the results of this study that even unmarried crews have had sexual relations with friends or girlfriends. The results of other studies stated that risky sexual behavior in truckers at Tanjung Emas Port was supported by the work environment of respondents such as the availability of entertainment venues, as well as the support of colleagues that allowed respondents to access sexual transactions easily[12]. The number of sexual partners of more than 1 is also related to the results of HIV testing. According to Astutik [13] the large number of sexual partners is a risk factor for STIs.

The results of this study found $2 \mathrm{ABK}$ who often changed partners to get the results of HIV reactive examination. Changing partners frequently is the biggest risk factor for contracting HIV after being controlled by other factors. ABK who often change sexual partners will have a 32 times greater risk of getting HIV than those who do not. This is in line with Bearinger [14] which states that more and more sexual partners are more likely to be exposed to an STI. Budiati [9] in the results of his research stated there were 3 risk factors for STIs in Juwana Port, namely agent, host, and environment. Hosts or IMS hosts in general are human. Individuals who are at high risk are individuals who frequently change partners. From the findings in the field, it was obtained information that sometimes there were some women who were on ships who claimed to be sales but it was not known for sure whether they only sold their products or sold their services (selling sex to ABK). Environmental factors greatly affect STIs in ABK, especially the habits of some ABK who often sex buying. The ABK environment requires ABK to work for months so that their biological needs are sometimes not fulfilled by their partners so that often some of ABK choose to use the services of female sex workers 
[15].

While the frequency of having sex, condom use, and alcohol consumption did not get a relationship with the results of HIV testing. The frequency of sexual intercourse in ABK is not related to the results of HIV testing. This is different from what was said by Kusnsan [16] that the more frequency of sexual intercourse carried out the higher the incidence of STIs in SW respondents. No matter how many guests / customers and whenever a guest or customer wants to date him, he will still be served. As many as $38.7 \%$ receive customers $>3$ people every week, the rest is not necessarily around 1 or 2 every week. But this does not apply to ABK as users of sex services. The use of condoms is not related to the results of HIV testing. As many as 1 respondent who used condoms got reactive examination results. As much as $21.7 \%$ of $\mathrm{ABK}$ use condoms during sexual intercourse, either with their wives, prostitutes, or boyfriends. It can be stated that condom use in ABK is still lacking, because respondents who have sex with non-partners are 23.3\%. This is similar to the results ofresearch Sirait's [17] that as much as $23.2 \%$ of ABK use condoms well. This proportion is higher than the results of the $\mathrm{STBP}^{10}$ only $8 \%$ of condom use during sexual intercourse with PSK and non-permanent partners. PSK encouragement variables, knowledge, perceived susceptibility, perceived severity ofAIDS, perceived benefits, and perceived self efficacy have a significant relationship with the action of using ABK condoms [17].

The results of this study were $33.3 \%$ of ABK who consumed alcohol. Length and duration of work, lack of religious attachment, and ignorance of the maximum level of alcohol allowed to be consumed are factors that cause alcohol consumption in seafarers [18]. However, alcohol consumption in this study was not related to the results of HIV testing. This is not in line withstudy Bearinger's [14] which states that people who drink alcohol can be less selective in choosing a sexual partner and make it difficult to use condoms properly. Another study of five seafarers in Uganda with an average high HIV infection found that it was associated with risky behavior including alcohol consumption habits [19, 20]. But in another study it was stated that empirically, the use of alcohol and illegal drugs did only have a not so large correlation to risky sexual behavior. The smallest value correlation coefficient appears in the role of alcohol in predicting risky sexual behavior and the role of alcohol and drugs in predicting the number of sex partners. Many other variables are predictors of risky sexual behavior, such as personality seeking sexual sensation, knowledge of AIDS, attitudes to condom use, condom use, self-esteem, parent-child communication, peer pressure, and so on [21].

\section{CONCLUSION}

Based on the results of the study it can be concluded that STI risk factors that are associated with HIV incidence are variables of sex with non-permanent partners, frequent partners, number of sex partners, and buying sex. There was no relationship between the frequency of sex, condom use, alcohol consumption and the incidence of HIV. The most dominant factor associated with the incidence of HIV is often changing partners with an OR value of 32.173. From the results of the study found that there are still risky sexual behaviors that can affect the transmission of HIV in ABK, it is suggested that efforts to improve HIV prevention education with various methods so as not to increase the incidence of HIV in Indonesia. For ABK, it should increase self-awareness that risky sexual behavior will have a detrimental effect, not only on itself, but on their families and environment, and will cause STIs which lead to death. The need for crosssectoral cooperation of the community, whether family, workplace or company, health sector, religious sector, education sector as a joint effort in preventing the transmission of out-of-sex diseases, especially HIV.

\section{REFERENCES}

[1] Ditjen P2P Kementerian Kesehatan RI. Laporan Situasi Perkembangan HIV-AIDS\&PIMS di Indonesia JuliSeptember 2016. Jakarta: Kementerian Kesehatan RI; 2016.

[2] Komisi Penanggulangan AIDS Nasional (KPAN). Strategi Nasional Penanggulangan HIV dan AIDS 2010-2014. Jakarta: KPAN; 2010.

[3] Dadun, dkk. Perilaku Seks Tak-Aman Pekerja Berpindah Di Pantai Utara Jawa Dan Sumatra Utara Tahun 2007. Jurnal Kesehatan Reproduksi. Vol 1(2):92-101, 2011.

[4] Rokhmah, Dewi. Implikasi Mobilitas Penduduk Dan Gaya Hidup Seksual Terhadap Penularan HIV/AIDS. KEMAS. Vol. 9(2):183-90, 2014.

[5] Azim, T., Khan, S.I., Haseen, F., Huq, N.L., Henning, L., Pervez, M., et al. HIV and AIDS in Bangladesh. J Health Popul Nutr. Vol.26(3):311-24, 2008. 
[6] Setiawan, I.M. Social risk networks and HIV/AIDS among fishing boat crews in Benoa Port, Bali. 2008.[Cited on12 Agustus 2017] Available at http://kink.onesearch.id/SummonRecord/FETCHproquest_journals_3043396343

[7] Kramer, M. Travel and migration: HIV and STIs among ethnic groups in the Netherlands. UvA-DARE (Digital Academic Repository). Available at http://pure.uva.nl, 2011.

[8] Jabbari, H., Aghamollaie, S., Djavid, G.E., Sedaghat, A., Sargolzaei, M., Alinaghi, S.A.S., et al. Frequency Of HIV infection among sailors in south of Iran by rapid HIV test. AIDS Research and Treatment. Iran: Hindawi Publishing Corporation; 2011.

[9] Budiati, R.E. Risiko infeksi menular seksual pada anak buah kapal di Pelabuhan Juwana Pati. Jurnal Kesehatan Masyarakat STIKES Cendekia Utama Kudus. Vol.5(1):1-11, 2017.

[10] Kementerian Kesehatan RI. Laporan Surveilans Terpadu-Biologis Perilaku (STBP) 2011 (Integrated Biological and Behavioral Surveillance). Jakarta: Direktorat Pengendalian Penyakit dan Penyehatan Lingkungan; 2011.

[11] Komisi Penanggulangan AIDS Nasional (KPAN). Rangkuman Eksekutif Upaya Penanggulangan HIV dan AIDS di Indonesia 2006 - 2011. Jakarta: KPAN; 2011.

[12] Winahyu, L., Husodo, B.T., Indraswari, R. Faktor-faktor yang berhubungan dengan perilaku seksual berisiko pada trucker di Pelabuhan Tanjung Emas Semarang. Jurnal Kesehatan Masyarakat. Vol. 4(5), 2016

[13] Astutik, Y.D. Faktor yang berhubungan dengan kejadian gonore pada waria di Surabaya tahun 2011 [Skripsi]. Surabaya: Universitas Erlangga; 2011.

[14] Bearinger, L. H., Sieving, R. F., Ferguson, J., \& Sharma, V. Global perspective on the sexual and reproductive health of adolescent: Patterns, prevention, and potensial. Amsterdam: Lancet; 2007.

[15] Najmah. Epidemiologi Penyakit Menular. Jakarta: CV.Trans Info Media; 2016.

[16] Kusnsan, A. Analisis Hubungan Determinan Kejadian Penyakit Infeksi Menular Seksual (IMS) Pada Wanita Penjaja Seksual (WPS). Jurnal Kesehatan. Vol.4(2): 344-50, 2013.

[17] Sirait, L.M., Sarumpaet, S. Hubungan Komponen Health Belief Model (HBM) Dengan Penggunaan Kondom Pada Anak Buah Kapal (ABK) Di Pelabuhan Belawan. Jurnal Precure. Vol.1(1): 43-9, 2013.

[18] Ribeiro, C.R.B., Saboia, V.M., Pereira, C.M. Alcohol consumption among fishermen: an integrative review. Fund Care Online. Vol.9(2):575-82, 2017.

[19] Asiki, G., et al. HIV and syphilis prevalence and associated risk factors among fishing communities of Lake Victoria, Uganda. Sex Transm Infect. Vol.87(6):511-15, 2011.

[20] Seeley, J., et al. High HIV incidence and socio-behavioral risk patterns in fishing communities on the shores of Lake Victoria, Uganda. Sex Transm Dis. Vol.39(6):433-39, 2012.

[21] Rahardjo, W. Konsumsi alkohol, obat-obatan terlarang dan perilaku seks berisiko: suatu studi meta-analisis. Jurnal Psikologi. Vol.35(1):80-100, 2008. 